\title{
Postmodern Conceptualization of Focalization, Temporality and Spatiality as Three Narrative Aspects in Darren Greer's Just Beneath My Skin (2014)
}

Nadia Hashish

Assistant Professor, Faculty of Arts, Ain Shams University, Egypt

\begin{abstract}
Although most of the existing postmodern and contemporary theories of narrativity may claim their great disparity from the earlier classic and modern ones, some of their narrative aspects seem to be at a very close distance from the earlier ones, especially those related to content such as themes and characterization. Other narrative aspects that have indeed undergone great deviance from the so long accepted modern interpretations are not paid a highly considerable attention in the field of literary studies, especially those concerned with form criteria such as narrative style, narrator, focalizer, point of view, temporal distortion and spatial form. Thus, this paper aims to explore three narrative aspects that cause a radical change in the classic and modern narrative theory, namely; focalization, temporality
\end{abstract}

and spatiality. Besides, it examines postmodern conceptualization of these three aspects through some literary theories such as Gerard Genette's Theory of Focalization, Mikhail Bakhtin's Theory of Dialogic Novilistic Style, Louise Rosenblatt's Reader's Response Theory, or Literary Transaction Theory as she prefers to call it, and Mark Turner's and others' Cognitive Narratology Theory which is a branch of Cognitive Literary Critical Studies Theory. These theories provide the appropriate theoretical tools for the study and understanding of postmodern and contemporary fiction in general and the novel at study in particular. Since narrativity is the core of literary texts and non- literary media, Darren Greer's novel Just Beneath my Skin is chosen as a practical textual literary corpus where the forces of the three innovative aspects of narrative theory are seen at work. 


\section{Postmodern Conceptualization of Focalization, Temporality and Spatiality as Three Narrative Aspects in Darren Greer's Just Beneath My Skin (2014)}

Nadia Hashish

Although postmodern theories of narrativity may claim their great disparity from the earlier classic and modern ones, they all share common narrative aspects especially those related to content such as themes and characterization. Other narrative aspects that have indeed undergone great deviance from the so long accepted modern interpretations are not paid a highly considerable attention in the field of literary studies, especially those concerned with form criteria such as narrative style, narrator, point of view, temporal distortion and spatial form. Thus, this paper aims to explore three postmodern narrative aspects ${ }^{1}$ that cause a radical change in the classic and modern narrative theory; namely; focalization, temporality and spatiality.

It also attempts to examine postmodern conceptualization of these three narrative aspects through restructuring them within the theoretical framework provided by relevant critical literary theories such as Gerard Genette's Theory of Focalization, Mikhail Bakhtin's Theory of Dialogic Novilistic Style, Louise Rosenblatt's Reader's Response Theory, or Literary Transaction Theory as she prefers to call it, and Mark Turner's and others' Cognitive Narratology Theory which is a branch of Cognitive Literary Critical Studies Theory. These theories provide the appropriate theoretical tools for the study and understanding of postmodern and contemporary fiction in general and Darren Greer's ${ }^{2}$ novel Just Beneath my
Skin (2014) in particular. Since narrativity is the core of literary texts and nonliterary media, Just Beneath My Skin is chosen as a practical textual literary corpus where the forces of the three innovative aspects of narrative theory are seen at work.

"In postmodernist texts, ...", as Brian Mc Hale states in his book Postmodernist Fiction, "epistemology is backgrounded, as the price for foregrounding ontology" (11). He postulates that the most significant factor which actually sets postmodern narrative aspects as clearly distinct from their predecessor modern ones is their being hued with that ontological tinge in dealing with all that problematizes the late twentieth century world which witnesses the rise of postmodernism as a literary critical theory, this very fact which characterizes almost all the postmodern and contemporary narrative fiction. Accordingly, beside offering a postmodern, innovative experiment with the writing form, Greer's novel is a postmodern text that clearly demonstrates the postmodern ontological turn and follows its parameters in its presentation of the three chosen narrative aspects.

Just Beneath My Skin opens with the return of Jake Mc Neil to North River; his small, job- ridden, welfare- supported, dying hometown. He has been away for six months to work in the big, cosmopolitan city of Halifax and decides to take his eight- year old son, Nathan, to 
live with him there and lead a wellafforded, secure and better life. Though an unexceptional, middle class worker at the town mill, he is the only one in the novel to decide to break off the circle of his unpromising, everyday quotidian life amongest dangerous, drug- addicted friends and a drunkard wife and escape an apparently doomed town mired in poverty, drug addiction, violence and despair. The whole action takes place on one day, but renders a background story of four generations of the Mc Neil family; Jake's grandfather, Jake's father; Reverend Mc Neil, Jake Mc Neil and Jake's son; Nathan through flashback and memory. Unfortunately, Jake's journey to take his son back is never accomplished as he is followed by a dangerous friend from the past who decides to take his life first and end his prospective dream of breaking through this vicious circle forever.

Focalization is the first postmodern narrative aspect to be explored in Greer's novel. The word is a neologism that is coined by Genette in his 1972 book Narrative Discourse: An Essay in Method. In it, he introduces the term Focalization to replace the traditional perspective, or point- of- view paradigm. He believes that the new term is fairly more accurate because he sees that the traditional point of view does not properly indicate the restriction of the amount of narrative information in relation to the amount of knowledge of any narrative entity such as a narrator, or a character in the narrative.

Genette's theory of Focalization is significant for its new approach to the field of such narrative aspects as point of view. It is an original theory because Genette could differentiate, for the first time, between the two concepts of perspective, or point of view agent and narrating agent, or in other words, between the focalizer and the narrator. His critical, theoretical postulates on focalization are of great value here. In his book, he explains that:

point of view is, of all the questions having to do with narrative technique, the one that has been most frequently studied since the end of the nineteenth century, ... However, to my mind most of the theoretical works on this subject ... suffer from ... a confusion between the question who is the character whose point of view orients the narrative perspective? And the very different question who is the narrator?- or, more simply, the question who sees and the question who speaks? (287)

In Just Beneath My Skin, it is always Jake "who sees" and the whole narrative is focalized on one main narrator; Jake, the focalizer, who is also the main character. Though the action unfolds through alternating narrators; Jake and Nathan, Jake acts as a common factor in the three parts of the novel. Even in the parts which Nathan narrates, Jake is always referred to as he occupies Nathan's mind and memory. Thus, Jake is always present whether, internally, as a direct participant in the action through his position as one narrator, or, externally, as a continuous reference in the action through Nathan who acts as the second narrator.

Accordingly, the focalizer's perspective must direct the action in the narrative, whereas the narrator's does not direct it. The focalizer must, then, be a narrator, but the narrator is not necessarily considered a focalizer. Further, Genette suggests that there are three types of Focalization; zero, internal and external. He states that: 
The first Term corresponds to what English- language criticism calls the narrative with omnicient narrator ... and which Todorov symbolizes by the formula Narrator $>$ Character (where the narrato knows more than the character, or more exactly says more than any of the characters know). In the second term, Narrator= Character (the narrator says only what a given character knows) this is the narrative ... with "restricted field" ... In the third term, Narrator $<$ Character (the narrator says less than the character knows); this is the "objective" of"behaviorist" narrative ... (188-9)

In Just Beneath My Skin, the type of focalization that is clearly observed is the second type; internal focalization since Jake, the narrator and the main character are one. Their focus is on the same inner thoughts and feelings. Though the "use of the 'first person,' or better yet, oneness of person of the narrator and the hero, does not at all imply that the narrative is focalized through the hero" (Genette 198), this is not the case in Greer's novel. In Just Beneath My Skin, Jake is the first narrator and the focalizer, or the focal hero at the same time whereas Nathan does not transgress his role as the second narrator only.

The novel opens, for instance, with Nathan seeing Jake back in town standing with his old dangerous company. He asks him if he is coming over to their house and meeting his mother. Jake assures Nathan that he will:

"Well, then ...tell her I'll drop around tonight and that when I do

I want to talk to her."
"Okay, Jake. I will. What do you want to talk to Mom about?"

"None of your business," Jake says. "Now git." (5)

Like Jake the narrator, Jake the focalizer, or the focal hero knows the real aim of his visit to Carla, his wife, but, Jake the narrator chooses to hide this information from the reader all through Part I. It is only in Part II, near the middle of the novel that the main aim of his visit is revealed. He tells Carla: "I want Nathan" (105) To dissuade him from this enterprise of taking Nathan, Carla keeps teasing him that Nathan is not his son. His negotiations with Carla end in a boy- for- money deal. These bits of information are conducted through Nathan, the second narrator. Genette's definition is worth noting in this respect: "Internal focalization, is the omission of some important action or thought of the focal hero, which neither the hero nor the narrator can be ignorant of but which the narrator chooses to conceal from the reader (196).

At Johnny's, before leaving to see Carla and Nathan, Jake, the focalizer/ hero expresses his inner fear of Johnny who keeps him unwillingly at his place:

"Well, you try to leave ... and my finger on the trigger. You won't make it to your car."

"Jesus, Johnny," I say, feeling more scared suddenly than I had been. "Why are you doing this?"

"Because," Johnny answers, "You ain't the same, Mc Neil. The city's changed you, and I figure it's my job to change you back, or have you die trying. (59-60) 
Though Jake, the focalizer is afraid of Johnny, Jake the narrator does not tell the reader whether Johnny is really serious about killing him, or not. After being chased into the woods by Johnny, Jake could escape by wading into the river leaving Johnny at the bank shouting and threatening.

Jake, the narrator deceives the reader, or rather intentionally hides an information when two pages before the end of Part I, he says: "The shot comes. The explosion echoes up and down the river and suddenly I am under water and being carried away by the current" (93). The reader thinks that Jake is dead. When the focalizer chooses to accelerate the tension, the second narrator, Nathan extenuates it. Thus, Part I ends with the discovery that Jake appears at Carla's door "soaked and shivering on the stoop with no Pinto behind him, and a bad scratch on his cheek and his wet hair plastered flat to his head" (95)

When Jake takes Nathan, he decides to go again to Johnny's place to fetch his car. The narrator's restriction of the amount of narrative information is almost equal to that of the character and the reader follows them with heightened suspense to see what happens next. Jake, the focalizer is very decisive and his perspective directs the coming action: "If I get out of this alive, I'm giving Nathan a better life. The river flows only one way" (173). However, Part II ends with a discovery that Jake, the narrator keeps concealed from the reader. At Johnny's yard, Jake, the narrator says: "I take another step. And another. And I am almost to the car when I realize something. I don't have the keys. They're still in the pocket of my jacket, and my jacket is in Johnny's cabin on the sofa where I left it" (176).
Jake also discovers that Charlie is dead because wearing his jacket, Johnny mistakes him for Jake. Jake, the focalizer confronts Johnny and accelerates the action:

"But why, Johnny?" I cry once more. "Why do you want to kill me?"

"I'll tell you why." Johnny says. "I'm tired of you, Mc Neil. You think you're better than me; I was put here to show you you ain't" (201-2)

Jake could successfully escape for the second time into the woods, but when he sees Johnny, at the end of Part III, pointing his gun at Nathan's head, he springs out of the woods only to get the shot himself. The reader is perplexed not knowing if Jake is really killed this time or not, even after Nathan, the second narrator, says: "Jake isn't moving" (215). However, it is only through Jake, the focalizer's final monologue in the other world that the reader is sure of Jake's death. It seems that Jake wants to keep his role as the focalizer/ hero till the end, a role which enables him to direct the action, control the line of narrative and write the end of an ordinary man whose life becomes a dear price for hope at the end of the first millenium.

In her article "Angela Carter and the Violent Distrust of Metanarratives", Ileana Botescu- Sireteanu stresses the importance of focalization in revealing the author's critical voice. This voice appears in the main narrative point of view. "In narrative theory," she states that "focalization appears to be the most important element in the narrative, next to the narrating instance, as it provides readers with crucial information for the sense- making process ... focalization provides important clues as 
to the authorial intention and quite meaningfully, ... as to the ideology behind the narrative" (113).

Focalization, indeed, becomes crucial when the narrative discourse provided by Jake is analysed because it is only through Jake that Greer is giving his ideological view points and it is only through all the other characters' discourses collectively that Greer is presenting the counter voice which he is against; that which is heard as powerful representation of patriarchal, authoritative, totalitarian social and cultural constructs such as religion, parenthood, veteranity, politics, history, heritage, myths, or tales.

The focalizer gains his important position from the fact that his own individual actions and behaviour are influential in the overall collective narrative. Jake's action of breaking off the vicious circle and leaving for work and better life in the big city is not a usual behaviour that is likely to be taken by any of the residents of North River. The same applies to the focalizer's language since it is as equally important as his actions as it reflects a discourse that is different from that of any social group and does not conform to the social norm with its versatile forms of patriarchal authority. Through Jake, Greer is actually defying all the existing patriarchal social constructs and their specific discourses, thus giving way to a voice that deviates from the social norm and seeks a decentered position away from the centered one already occupied by its patriarchal constructs.

Russian literary critic, theorist and philosopher Bakhtin introduces his theory of Dialogic Novilistic Style with its critical concept of dialogism, or dialogic discourse in his book The Dialogic Imagination:
Four Essays and this theory is of great relevance here since it complements the idea of focalization as it highlights the importance of the focalizer's language. Language for Bakhtin, as he explains in his book, is a living entity and what creates life for a language and shares in its evolution is the continuous work of forces in the verbal- ideological discourse of different social groups. These forces which "serve to unify and centralize the verbalideological world" (270) lead to a formation of what Bakhtin calls a unitary language. What interests him is the fact that centripetal forces that are embodied in the life of this unitary language "operate in the middle of heteroglossia" (271). This heteroglossia with its centrifugal forces, for him, insures the dynamics of the language itself and continues to do so as long as the language is alive.

Thus, Bakhtin suggests that "alongside verbal- ideological centralization and unification, the uninterrupted processes of decentralization and disunification go forward" (272). He sees language, like life, as two sets of two conflicting forces; the official, central, centripetal forces set in opposition to and in interaction with the everyday, decentralized, centrifugal, dialogized, heteroglossic ones. For this reason, he believes that a novel is the only genre which could show this dialogic heteroglossia by virtue of its prose language which provides an ample space for both of the centripetal and centrifugal forces to go side by side to present a form of democratic, multi- voiced discourse instead of a totalitarian, monologic one.

Bakhtin's theoretical approach to language corresponds to and further explains the important role of the focalizer's language in the overall narrative fabric. His theory of Dialogic Novilistic 
Style is of great relevance to analyze Greer's narrative style in Just Beneath My Skin due to the fact that it explains how dialogic heteroglossia result in providing the two discourses which belong to two social strata; the patriarchal, authoritative, mainstream majority and the individual, resilient, striving minority. Greer seems to assert that different as these two discourses are, they are also complementary and need to exist side by side in any healthy society. The novel teems with speech diversity that Greer seems to listen to and react with its multi- voicedness; the basic heteroglossia dwelled in the actual language of the characters of the novel. He can get hold of their social overtones and is attentive, to quote Bakhtin's words, to "the doublevoicedness and to the internal dialogization of living and evolving discourse" (324).

Literary language, for Bakhtin, "is itself stratified and heteroglot in its aspects as an expressive system, that is, in the forms that carry its meanings" (Bakhtin 289). Thus, the different languages of the characters in Just Beneath My Skin differ in their vocabulary, or the jargons used according to each character's social stratification and they also manifest "forms for making" (Bakhtin 289) abstract conceptualization and evaluation materialized language possibilities. Accordingly, with the exclusion of Jake, the characters' language is unitary and reveals their social stratification. At the same time, it reflects the collective patriarchal discourse that governs the closed society of North River. Four discourses, for instance, belong to the patriarchal authorities in Jake's world; those of veteranity, religion, folk tales and evil company.

First, the language of Jake's grandfather offers the discourse of the veteran who returns from World War II with a sense of delusion and disappointment. He is seen in one episode in Jake's memory giving his life/ war experience to Jake, his almost thirteenyear- old grandson: "The secret of the world is not an eye for eye or turn the other cheek. The secret of the world is not to get in any goddamned trouble in the first place" (Greer 181). He does not want to be buried in uniform. He does not want to talk about his war experience, his march into Bergen Belsen with the Allied forces, or the concentration camps. He returns to his small Nova Scotian town with a blood stained Nazi flag to burn. Before going to the war, his view of life used to be built on epistemic concerns; he used to question the 'how' of the matter all the time, but after the unimaginable experience of the war, he starts to consider the ontological concerns; he starts to question the 'what' of the matter, like what kind of world they are really living in.

Reverend Mc Neil, Jake's father acts as the second one of the four main patriarchal authorities in Jake's world as he represents the religious institution being himself a minister. His language is also representative of the religious authority. He used to tell Jake: "The river flows only one way" (Greer7). Jake never understands what his father means at the time, but he, nevertheless, sticks to his own individual way to break off the circle and cause a difference in the mundane life of his son which he fails to do with his own life earlier. Life, for Reverend Mc Neil, is immersed in epistemological concerns. It is a continuous road of suffering that flows, like a river, one way. It is a battle between the forces of goodness and those of evil and it will never change till the end when man attains salvation. At church, 
after attending one of Reverend Mc Neil's services, Nathan, his grandson, assures him that he is a believer despite the heathen name of "Alexander" that Jake gives him. Nathan speaks with his grand dad in the religious language that he understands quoting one of his mother's neighbours: "Irene Lang says Jesus is a part of everything. That He's just beneath everything, like the Earth or air, something that's always there but that sometimes you don't think about or can't see. But it's holding you up and keeping you alive just the same. ... 'Jesus is just beneath the skin"' (Greer 162).

Few hours before Jake's grandfather dies, he advises Jake not to listen to the words of his father and his grandmother and be a preacher. In deviating him from the imposition of his father's religious authority, he seems to drag him to the influence of another authority of different nature, that of the disbelievers. He tells Jake: "Don't let them talk you into being a preacher. That life is fine for some, Jacob. But you and I see things the way they don't. There's two ways of reading the world. Through a book, or through your own eyes. Ain't nothing wrong with either, but we all gotta figure out which way is good for us" (Greer 180).

Jake's grandfather seems to recommend for Jake the ontological approach in dealing with the real world in which he lives as opposed to the epistemological approach adopted by his father. His philosophy in life is different from that of Jake's father, but both of them act as two different examples of the patriarchal discourse. At twelve, Jake once witnesses one of their arguments about the Bible: "my grandfather said, 'if it were an eye for an eye we'd go over there and turn every one of those damn Germans into lamps.'
My father only shook his head. 'It's not an eye for an eye. Jesus changed all that.' 'He didn't change very goddamned much,' said my granfather" (Greer 181).

The third example is embodied in the language of Irene Lang, Jake and his wife Carla's neighbour who represents folk tales as another influential authority in the society. When Lucy, another neighbour's baby dies of crib death, Lang talks with Carla about it the next day. Nathan, a young boy, is frightened by such tales. He dreams of the dead Lucy and could not sleep well for a time. He narrates: "That's how they found Lucy. Blue and cold. I heard Irene telling Mom the day after it happened. "As blue and cold as a fish," said Irene. "I swear she was. Poor thing must have been dead for hours" (Greer 11).

The fourth authority is felt in the language of the evil company, criminals and losers which is represented by the figure of Johnny Lang, a drunkard, drug addict and criminal. He kills his father because of his bad treatment to his dying mother. He tells Jake once: "'I meant to kill him, you know.' ... 'Him,' he said. 'Him. I meant to do it. I wanted to do it" (28-9). Though he has a cause for killing his father, Johnny has none for killing Charlie, his friend later on. He tells Jake: "'It was an accident.' says Johnny. 'It was dark. I was high. I thought it was you. He was wearing your jacket"' (201). He tells Jake why he wants to kill him. Johnny feels that he could not drag Jake back to his circle of losers, that's why he decides to get rid of him.

Against the discourse of these four patriarchal authorities acting upon Jake's life, Jake's discourse, as the focalizer's, emerges to oppose them all. Jake has taken 
his decision to leave with Nathan and he is not going to sacrifice it at any rate. Since his college years, he only likes Six Characters in Search of an Author, an Italian play by Pirandello. He sees himself as one of these characters who need an author to write their story. He comments: "Sometimes that's the way I felt in North River. Like we were all living the same lives over and over again, with no way out, with no one to write us. I had my chance, I suppose, but I blew it when I quit university. That's why I went to Halifax the second time. To be written" (Greer 54) Unfortunately, because the river flows only one way in North River and Jake insists to attempt struggling against the current, his life becomes a good price for the attempt.

To follow the untraditional line of narrative in Greer's Just Beneath My Skin, to decipher the nature of the two different discourses; those of Jake versus all the other characters, and to understand the overall meaning of the novel is not an easy mission at all. The reader's role in deciphering the meaning should be emphasized to accomplish this task. It is worthnoting that in the circles of critical theory, theoretical discussions have amply dealt with the relationship between reader and text. With the romantics, literary criticism is author- oriented, with the advent of New Criticism, it becomes textoriented and with Reader- Response theory that appears in the seventies and the eighties in opposition to New Criticism, the emphasis is more reader- oriented.

The relationship between reader and text has gained much attention with Rosenblatt, the first one to coin the term of Reader's- Response theory. She, however, prefers to narrow down the broad connotations of the word 'response' and change it into Literary Transaction theory. In her interview with Nicholas J. Karolides in "Theory and Practice: An Interview With Louise M. Rosenblatt", she states that the reason behind this preference is "to emphasize the reciprocal importance of both reader and text" (167).

In her article "The Literary Transaction: Evocation and Response", Rosenblatt introduces her approach to the reading process and the role of the reader. She sees that the literary work is "not ready- made in the text, waiting to imprint itself on the blank tape of the reader's mind" (268). Rather, the reader starts an act of transaction with the text. He/ she reacts with the text, frequently consulting his/ her past reservoir of world experience, language and ideas, thus creating frameworks in which he/she fits the new ideas from the text to reach the meaning. Rosenblatt states that "Reading is a transaction, a two- way process involving a reader and a text at a particular time under particular circumstances" (268). Further, understanding a literary work of art does not only depend on the text, but also on the reader's mental set, or as Rosenblatt calls it "stance of the reader" (269) which is crucial to get a meaning out of a text.

Understanding the meaning in Just Beneath My Skin depends on the reader's chosen stance; if he/ she is carrying on an "efferent reading" ("The Literary Transaction: Evocation and Response" 268), hence looking for the final meaning only, or an "aesthetic reading" ("The Literary Transaction: Evocation and Response" 268), hence allowing the appearance of feelings, ideas and imagination. Since Greer's novel is a literary work of art, a reader is most likely inclined to approach it aesthetically to 
understand it. Rosenblatt further explains that

In an aesthetic reading, we respond to the very story or poem that we are evoking during the transaction with the text. In order to shape the work, we draw on our reservoir of past experience with people and the world, our past inner linkage of words and things, our past encounters with spoken or written texts. We listen to the sound of the words in the inner ear; we lend our sensations, our emotions, our sense of being alive, to the new experience which, we feel, corresponds to the text. We participate in the story, we identify with the characters, we share their conflicts and their feelings. ("The Literary Transaction: Evocation and Response" 270)

Accordingly, the reader of Just Beneath My Skin plays an active and basic role in reading and understanding the text. Besides, reading itself is basically a transaction and a creative activity. Rosenblatt's critical theory is very relevant to understand the meaning in Greer's novel. Though the language of the novel is easy, the novel itself is not simple to understand. Many factors contribute to the difficulty of arriving at a meaning. It is not written in the traditional, linear way, the events are not chronologically ordered, the action is laid by two narrators who give their own alternative perspectives, time is distorted and space is undefined. These factors evidently impede an easy access to the meaning of the novel and the reader needs to exert too much effort and engage in a real reading activity by transacting with the text itself to reach the meaning. Rosenblatt affirms that meaning is not already defined in a text waiting to be revealed by the reader. Physically, the text is made up of just marks on paper with no meaning set in advance until a certain reader starts the activity of seeking meaning by transacting with this particular text in a particular time. In her article "The Aesthetic Transaction", she comments that What happens, then, is that each particular reader "brings a unique reservoir of public and private significances, the residue of past experiences with language and texts in life situations. The transaction with the signs of the text activates a two- way, or, better, circular, stream of dynamically intermingled symbolizations which mutually reverberate and merge" (123).

Since possibilities offered by signs in the text are infinite, a reader has to be highly selective and focused to make a meaning that fits within a certain framework, or roadmap he/ she has developed during the reading process to guide him/ her in the journey towards reaching a meaning. He/ she contemplates "diction, syntax, ideas, subject, themes, linguistic and literary conventions" ("The Aesthetic Transaction" 123). In the process, he/ she "signals certain possibilities and excludes others, satisfies or frustrates earlier expectations, thus shaping, testing, and revising, not only the developing structure of meaning, but also the selective principle itself. If symbolizations arise that cannot be assimilated into the emerging synthesis, a complete rereading and revision may occur" ("The Aesthetic Transaction" 123).

This theory helps explain precisely what happens in the reading process of the novel. In Just Beneath My Skin, for instance, the reader can distinguish between the discourse of Jake, the focalizer, and the counter discourse of all 
the other characters. The reader is also alert to the behaviour of different characters, thus, on the one hand, he/ she identifies with Jake's attempt for leading a better life and with Nathan's innocent toleration of a miserable childhood. On the other hand, the reader does not approve of Johnny's aggressive behaviour towards Jake. The act of shooting his father at an early age is actually foreshadowing his shooting of Jake later on in the novel.

Most importantly though, the reader discovers the discrepancy between his expectations of the novel and the reality of the world depicted in the novel. As readers, Rosenblatt adds: "We may be aware of a contrast between the assumptions or expectations about life that we brought to the reading and the attitudes, moral codes, social situations we are living through in the world created in transaction with the text" ("The Literary Transaction: Evocation and Response" 270). The reader, for instance, expects Jake to fulfil his mission and take Nathan with him to the big city all throughout the novel. Jake goes to talk with Clara, his wife and gives her money to let Nathan go with him. Then, he keeps Nathan at his father's house to fetch his car from Johnny's place. Johnny's chasing of Jake, after that, might have shattered the possibility of achieving Jake's dream, but Jake's success to escape renews the reader's hope that Jake will achieve his goal. However, the lived- in experience in real life proves to be more powerful than individuals' personal expectations.

Though Jake can escape Johnny's chasing for the second time in the novel, and go into the woods, thus creating another glimpse of hope for the reader, he emerges from the woods to face Johnny's gun when he sees it pointed at Nathan.
Greer is successful in holding the reader's breath and increasing his suspense till the end of the novel, giving him occasional moments of expecting Jake to go on with his prospective plan. However, the hope wanes as the novel approaches its end on the final three pages till it is completely lost with the shooting: "Being Shot is Nothing Like they say it is in books or movies. It's not a slow dying. It's a quick death" (214).

Temporality is the second narrative aspect to be explored in Greer's novel where the use of non- linear, narrative time element and temporal displacement distorts, or reconstructs the reality by questioning the epistemological logic and set of beliefs that govern the time perspective of the modern world and by highlighting the ontological, contemporary leap into a postmodern time perspective. Genette's comment on temporality distinguishes between its real and its fictional qualities:

Narrative is a ... doubly temporal sequence ...: There is the time of the thing told and the time of the narrative (the time of the signified and the time of the signifier). This duality not only renders possible all the temporal distortions that are commonplace in narratives (three years of the hero's life summed up in two sentences of the novel or in few shots of a "frequentative" montage in film, etc.). More basically, it invites us to consider that one of the functions of narrative is to invent one time scheme in terms of another time scheme. (33)

In accordance with Genette, Ana Sentov, in her article "The Postmodern Perspective of Time in Peter Ackroyd's 
Hawksmoor", says: "one of the features of postmodern novels is to organize narrative time in non- linear fashion and to present the story line as fragmented and disrupted. ... Non- linear time is incorporated in the fabric of the real, not distanced from it, so the reader has to accept this concept of time in order to understand the novel" (123-4). In Just Beneath My Skin, Greer reconstructs the linear, narrative time element in two ways; the first of which is through his frequent going back in time, thus reversing the traditional, onward, linear direction of the narrative time element. The second one is through using historically discontinuous sets of narrative time that are not chronologically ordered, but that are socially and culturally picked throughout the life span of the four generations of the Mc Neil family.

The novel is divided into three parts covering a one day, precisely about ten hours of historical time; from morning till evening and alternating fragmented episodes between the two main protagonists; Jake Mc Neil and his son Nathan. There are two parallel time lines; the first which sets the whole action on one day and the second which runs through several decades since the time of World War II in the mid- twentieth century to the late twentieth century featuring incidents in the lives of the four generations of the Mc Neil family. This is where Greer manages to experiment with the innovative, postmodern, narrative temporality.

The two narrative time lines are parallel in path, but whereas the first moves forward in a traditional, unidirectional, linear form to maintain the development of the plot, the second moves backward in an innovative, multi- directional, non- linear form. The two narrators; Jake and Nathan, appear alternatively in the novel through the three parts to narrate the same story from the different perspectives of a grown up father and a young child respectively. Their travelling experience in narrative time is materialized by recalling incidents from the past which also alternate between the two characters.

In one episode, for instance, Jake recalls an incident when at five, his foot slips and he is about to die suffocating under a bale of hay at his grandfather's barn "wondering about the darkness because the bales had sealed me off from the world and the light" (Greer 40). In the following episode, Nathan also recalls a similar incident that happens to him at five when he is almost dead having "something called 'a summer complaint'" (Greer 42) and stays in hospital for a week. Similarly, each new episode shares some similar details with the following one. Many of similar incidents, accidents, images, rhythms, dreams, discussions of certain topics, or ideas appear in both narratives. Thus, Greer creates two parallel worlds which are related and tangential, most of the times, at some points in the two narrative time lines. Through this technique, he can keep the narrative sequence of the novel, but equally important is the fact that he uses these tangential points as points of confrontation of the characters' alternating different perspectives of the world, their conflicting view points and the innovative concepts of time.

Greer divides the second time line into a triple time scheme to depict the conflict among the different concepts of time and the underlying conflicting views that characterize them. The first time scheme is the mid- twentieth century in the years following World War II, the period which 
witnesses Jake's grandfather's recent experience at war and his journey back to his small hometown. The second time scheme revolves around Jake's father and his work as a minister in church. The third time scheme depicts a late twentieth century small maritime town society that encompassses Jake's and his son Nathan's social sphere and features ontological challenges of the age. The first and second time schemes are frequently referred to in the novel, but the third time scheme is mostly used.

To understand this idea of time distortion in Just Beneath My Skin, in addition to the two parrallel narrative time lines and the triple time scheme division of the second time line is one way of trying to decode the author's message. How this takes place can be explained within the scope of Cognitive Narratology which is one discipline of Cognitive Literary Criticism. Jana Kuzmikova' states in her article "Cognitive Literary Research as a Showcase of Multidisciplinary Concept of Science", that Cognitive Narratology "is concerned with mental representations and cognitive processes, which help us understand narrative texts" (302).

Turner's Theory of Blending is of great use here. The human mind is able to blend related words owing to the mind's previous knowledge of the language. In their article "A Mechanism of Creativity", Turner and Gilles Fauconnier express their view that "Literary works frequently prompts for highly intricate blending" (414). In Just Beneath My Skin, not only does Greer present four generations of the Mc Neil family, but he also presents different time schemes. These time schemes can be sensed from blending of many related words. Greer's mentioning, for instance, of Jake's grandfather's enrollment in World
War II presents a sense of the time of this particular war. Building on the reader's previous knowledge of World War II, the reader relies on his/ her mental operations to blend related words from the novel like "Bergen Belsen" (179), "Allied soldiers" (179), "a Nazi flag" (179), "veteran" (180), "uniform" (180), among many others, then process them mentally to reach a meaning.

Turner and Fauconnier see that research on blending is related to language. They argue that

expressions do not mean, but are prompts, usually minimal, to construct meanings by working with mental processes we already know. The meaning of an expression is never "right there in the words." Understanding an expression is never understanding "just what the words say"; the words themselves say nothing independent of the richly detailed knowledge and powerful cognitive processes we bring to bear. (409)

In her article "Narratology in the Twenty First Century: The Cognitive Approach to Narrative", Monika Fludernick also alludes to the crucial relationship between language and cognition. She states that "Language arises from our conceptualizations of the world, and analysis of language and language use is therefore crucially linked to our minds and how they interact with our nonmental environment" (925).

Greer has successfully challenged the modern conceptualization of unidirectional, linear narrative time and history by offering his own postmodern conceptualization of the reversed narrative time direction and the temporal distortion of the life span of four consecutive 
generations of the Mc Neil family. Complex as this temporal distortion might sound, the virtual marking lines between past and present seem to disappear rendering a conceptualization of an innovative narrative time element that regards both the past and the present as one main constituent element in the story line of each of the main characters' identities.

Spatiality, the third narrative aspect, has recently become a basic element of narrative theory. Though the study of spatial form is a crucial critical issue in modern narrative fiction, its relevance increases in postmodern and contemporary narrative one. Spatiality emerges in the last three decades, as Santa Arias said in his article "Rethinking Space: an Outsider's View of the Spatial Turn", "as a social theory" that "forced the recognition of space and place as both the contingent condition and the outcome of human activity, as a weaving dance of intentional actions and unintended consequences" (39). Spatiality, as a critical notion, is no longer a concern of the discipline of geography only as it has recently escaped its geographical confines, in the last thirty years, to feature in other areas of study such as literature and culture. Although the study of space and spatiality in any society is often concerned with the physical topography, stretches of landscape and social circumstances, it lately concentrates on the idea of spatiality as encompassing various discourses that reflect a social opinion, constitute a social order, define a certain locale, and, at times, enhance, or undermine social opportunities in this locale. Arias comments that "Critical geographies have provided the tools to challenge historicist approaches that view space as a given entity, inert and naturalized, in order to engage in an interpretative human geography. ... Space thus comes to have multiple, sometimes contradictory, layers of meaning; the spatial turn speaks with more than one voice" (30-1).

In other words, he highlights the important impact of the geographical spatiality on social relations, entanglements and power. Current critical examinations of space that started in the last three decades "moved away from the temporal or chronological basis of history to a view of history as place- based". (31) To know the past, it is not accurate enough to consider a certain time in the past, but it is also necessary to map places of this historical past.

Greer makes the focalizer in his novel remember the past event of World War II and the engagement of his grandfather in it, not by mentioning its real dates, but by describing the spatial scope of this historical past time which features the grandfather's life, work and occupations. Thus, Jake is presented in the novel to remember his grandfather's logging business with its minutest details of driving hundreds of logs down the river to reach the lumber mills. He once tells Jake: "It was a dangerous job. Men slipped and got crushed between two logs just as they were being tossed together on the currents, or drowned when they went all the way under and never got a break in the logs to come back up again" (Greer 8). This example shows the impact of space on the social circumstances and gives a tangible description of the spatial plane at the historical period of World War II, hence giving it its spacio- temporal quality and setting, or contours of place, articulating the centrality of the subjective discourse of the loggers at the time embodied in the 
voice of the grandfather and representing the experience of living under the imperial power of World War II. Jake's grandfather is not proud of his war experience at Bergen Belsen with the Allied soldiers. He tells his son "The day I got down back to Canada I kissed the ground outside the train station and swore I would never leave Nova Scotia again" (Greer 179). Spatiality seems to be "wrapped up in relation of power, discourse and ideology" (Arias 32) and critics "came to understand space and place as situated social practices produced and reproduced in the rhythms of everyday life" (Arias 32).

Topographical place is used in Just Beneath My Skin as an analytical tool for understanding spatial critical issues. The spatial element plays an influential role in helping the author designate his view points about crucial issues such as the relationship between the spatial zone depicted by the author and ideas of belonging, mobilisation, selfhood realization, metropolitan expansionism and community deterioration. Emphasizing such a role in his book Contemporary British Fiction and the Artistry of Space: Style, Landscape, Perception, David James refers to the fact that there is "an ongoing consideration of how landscapes today continue to play a vital role in the choices writers make about formal innovation" (N.Pag.). The fictional world of Just Beneath My Skin is set in North River, a meticulously chosen locale by Greer to present the work of its centrifugal forces at its utmost intensity; these very forces which lead Jake to take his decision of leaving for the big city. Thus, as James claims, "characters' decisions and their pivotal consequences are often intensified by the demands and opportunities of where they take place" (N. Pag.).
Therefore, the role of the locale is not just a topographical setting, or a background habitat, but it can be considered one of the liveliest characters of the narrative process. In reading a novel, one is usually immersed in the topographical description of the setting with its use of words, imagery, rhetorical figures of speech, elements of sound and colour. However, the process of one's enthrallment with the scenic effect of the physical depiction of space usually undermines, or neglects the attention to the analytical role of spatiality as an essential narrative aspect in the reader's linguistic and cognitive processes. Thus, a need arises for conceptualizing spatiality as a postmodern and contemporary narrative aspect that novelists often deal with in their experimentation with narrative style.

Mieke Bal refers to the importance of description, which is space- oriented, as it occupies a central position in a novel. She sees that its role is never undermined when compared to that of narration, which is time- oriented. In her article "On Meanings and Descriptions", she asserts that "Every detail is related to the whole; nothing is superfluous; nothing is irrelevant; nothing is meaningless." (131) Thus, Bal believes that description of places in a novel is complementary to the action. It is not an interruption to the narrative.

In his interview with Katiuscia Darici in "To Draw a Map is to Tell a Story: Interview With Dr. Robert T. Tally JR on Geocriticism", Robert T. Tally expresses his agreement with Bal's view point. He tells his interviewer that "We tend to think of maps as descriptive, since they are a spatial representation, as opposed to narrative, which goes from beginning to middle to end in a relentlessly temporal 
movement. But the novel, along with other narrative forms, always includes both, more or less combining the two discursive modes in creating a larger literary cartography" (32). Tally supports the emergence of geocriticism, or geocritical approach as an interdisciplinary field in literary theory. He even prefers to call the field "spatial literary studies" (33).

Jake suffers from an acute sense of alienation in his own small town with its ever lasting problems of poverty, stagnation and crime. His sense of disorientation in North River is the first step for a real striving for orientation in Halifax. In a question about the condition of 'being lost', Tally gives an answer to his interviewer saying "I think it is true that, to the degree to which we attempt to overcome our sense of alienation by real or figurative mapping, we are often placed in an even more bewildering territory as we come to recognize the complexity and dynamism of the spaces." (32) Though the idea of leaving to the big city is decisive on Jake's part, all his past memories take place within the spatial stretch of North River as if he is being tied up to that space.

Greer's treatment of the notion of postmodern spatiality in Just Beneath My Skin is set in contrast to its modern one. Though both modern and postmodern societies suffer from a sense of fragmentation and disintegration, their approaches to this feeling is completely different. Tally gives his consent to the idea that postmodern spaces are fragmented spaces. Further, he explains the different approaches of both modernism and postmodernism to this issue of spatial fragmentation and the consequent characters' sense of disorientation. He tells his interviewer:
There's a sort of modernist sensibility ... that strikes an elegiac note in suggesting that the formerly whole or integrated societies or forms have faded away or been actively destroyed, and what is left is broken. ... Arguably, the reconstellating or reformational project of shoring up these fragmentary ruins into a new whole is itself a modernist project. ... Postmodernism, supposedly, celebrated the fragmentary, and rather than reforming the parts into a new whole, postmodernists are thought to revel in the impossibility of grand re'cits, for instance. ... I believe that we find or create patterns amid the chaos, ...The fragments and the whole work together in a dynamic fashion to form and reform intelligible ensembles that can then be put to use. (30-1)

Tally's theoretical views explain Jake's actions in Just Beneath My Skin. Jake, ordinary as he is, attempts an extraordinary shift in both his and his son's life. Rather than retreating from life in a chaotic world full of crime, poverty and despair, he chooses to seek a possibility of living within the chaos.

Understanding spatiality as a postmodern aspect may draw on cognitive literary theory exactly like understanding focalization and temporality. In his book Basic Elements of Narrative, David Herman refers to the important role of cognitive studies in understanding spatiality in fiction. $\mathrm{He}$ states that "theorists of space in narrative have borrowed from psychological and psycholinguistic work on spatial cognition, as well as cognitive- linguistic research on 
how abilities and dispositions bound up with embodied human experience find reflexes in the structure and interpretation of language" (131). He also finds out through his theoretical research "how particular textual cues prompt interpreters to spatialize story worlds, that is, to build up mental representations of narrated domains as evolving configurations of participants, objects, and places" (131).

Herman's approach can be employed in Just Beneath My Skin, to explore how Greer's shifts in space through describing Jake's life in North River, or in Halifax enable the reader to visualize these spatial stretches and divide the story into spatial narrative fragments. The reader can also situate each fragment in a specific spatial plane according to his/ her own understanding of the different worlds introduced through these planes and presented in the novel. Besides, the different worlds situated within different spatial planes highlight the intensity of the conflict in Jake; between a world that ensnares him and another world that enthralls him.

In Just Beneath My Skin, Greer presents Jake as torn between two worlds: the first is occupied by him and describes his life in North River, and the second is projected by him and foregrounds his new life in the big city with Nathan. The first is primary, main, strong, centered and forceful world. The second is secondary, subordinate, weak, decentered and vulnerable world. Besides, these two worlds exist on two virtual, spatial levels; one is the real world which occupies the spatial zone "above Jake's Skin" and the other is the future world which is spatially "beneath Jake's skin". One is visible and already accessible, the other is embedded and has not been accessible yet. One is epistemological and the other is ontological. One is immersed in epistemic questions on how to know of and learn about Jake's inner conflicts and social tensions in his surrounding world which does not serve him right in his real life. The other poses ontic questions on what the real world that he lives in looks like and what the possibility to lead a new life in the big city will be. One, endlessly, attracts him to the social labyrinth and the other, he is attracted to in search of a way out of the labyrinth.

Jake's projected world nearly wins till the end of the novel when Jake is adamant to take Nathan to the new life in the big city. It is not until the last four pages of the novel when Jake's tormented situation between the two worlds is finally resolved. Jake's shooting by Johnny suddenly takes the reader from Jake's projected world back to his occupied one. Jake narrates:

The last thing I see is the face of my son, staring at me, looking

like he is about to cry.

The last thing I see is the face of my son.

I am your father, I want to say.

But I have no voice. (Greer 214)

The closure of the novel is open ended and the reader is not sure of Nathan's fate. Nathan's words which end the novel are very expressive: "I know Jake is dying, but I don't cry. Jake would be real proud of me." (Greer 217) Nathan's interior monologue suggests that Jake's attempt at freedom from his small town labyrinth is not undermined, or regarded as futile for it might find an extension in his son who internally assures himself that Jake would be proud of him. Jake's small town labyrinth becomes his small town tomb. It seems that there is no way out as Jake's 
father once tells him: "you make your bed, you lie in it". (Greer 13). It is also apparent that this is the doom of the first three generations of the Mc Neil family. However, this does not entail that Nathan, the fourth generation of the Mc Neil family will surely meet the same fate. Jake's death, at the end of the novel, may have drawn an end to the life of one personal attempt, but will not evidently draw an end to the ever lasting hope for freedom.

In Just Beneath My Skin, Greer challenges the modern conceptualization of the three narrative aspects under study by offering his own new version of postmodern conceptualization of these very aspects; focalization, temporal distortion and spatial disorientation. Through his use of these postmodern narrative aspects, Greer highlights the struggle of the socially peripheral to assert their own voices in a society governed by patriarchical imposition of well established authoritative social constructs which give legitimacy to the centered social position at the expense of the decentered one. Jake's death at the end of the novel typifies not the vulnerability of the weak voices, but the cruelty and harshness of patriarchal social systems which hush down any other voice than theirs.

\section{Notes}

1 Postmodern narrative fiction refers to a body of literary output that shares similar characteristics which are most likely to be different from modern narrative fiction as the prefix "post" entails. It is true that the postmodern era chronologically follows the modern one with its aftermath of two world wars, a general feeling of disappointment, scepticism and loss in a chaotic, merciless world governed by disparate powers, cold war politics and economic commodification of late twentieth century capitalism. Nevertheless, postmodern narrative fiction is not exclusively confined to this historical era because postmodernism itself is more appropriate to be regarded as ideologically oriented rather than historically located literary movement. It might be hard to set cut and dried criteria to designate postmodern narrative fiction, but on the whole, it seems to incline towards the use of nontraditional, innovative and experimental narrative aspects in both of its content and form. This does not, by any means, negate the fact that its roots can be traced as early as the fiction of the eighteenth, nineteenth and early twentieth centuries in Laurence Sterne (1713- 68), James Joyce (1882- 1941), or Virginia Woolf (1882- 1941) where unprecedented narrative aspects are employed. Such narrative aspects may share commonality with their postmodern counterparts specially in the use of the subjective first person point of view, the handling of the stream of consciousness technique, the deposition of the chronological, uni- directional temporal scheme and the movement within limitless, undefined spatial boundaries.

2 Darren Greer (1971- ) is an awardwinning author whose novel Just Beneath My Skin (2014) is the winner of the 2015 Thomas Raddall Atlantic Fiction Award and the official selection for the 2015 One Book Nova Scotia pick. It is also nominated for the 2015 Jim Connors Dartmouth Book Award and shortlisted for the 2015 ReLit Award. 


\section{Works Cited}

Arias, Santa. "Rethinking Space: an Outsider's View of the Spatial Turn". Springer, Geo Journal, Vol. 75, No 1, 2010, pp. 29- 41, http://www.jstor.org/stable/41148382

Bakhtin, M. M. The Dialogic Imagination: Four Essays. Trans. Caryl Emerson and Michael Holquist, University of Texas Press, 1981.

Bal, Mieke. "On Meanings and Descriptions". in Studies in $20^{\text {th }}$ Century Literature, "Getting the Message: On the Semiotics of Literary Signification", New Prairie Press, Vol. 6, Issue 1, Article 7, January, 1981, pp. 100- 148, https://doi.org/10.4148/2334- 4415.1629.

Botescu- Sireteanu, Ileana. "Angela Carter and the Violent Distrust of Metanarratives". in Postmodern Openings, Lumen Publishing House, Year 1, Vol. 3, September, 2010, pp. 93- 138.

Fludernick, Monika "Narratology in the Twenty First Century: The Cognitive Approach to Narrative". in PMLA, Modern Language Association, Vol. 125, No.4, October, 2010, pp. 924- 930, http://www.jstor.org/stable/41058291.

Genette, Gerard. Narrative Discourse: An Essay in Method. (1972) Trans. Jane E. Lewin, Cornell University Press, 1980.

Greer, Darren. Just Beneath My Skin. Cormorant Books Inc., 2014.

Herman, David. Basic Elements of Narrative. Wiley- Blackwell: A John $\quad$ Wiley \& Sons, Ltd., Publication, 2009.

James, David. Contemporary British Fiction and the Artistry of Space: Style, Landscape, Perception. Continuum International Publishing Group, 2008, www.continuumbooks.com.

Kuzmikova', Jana. "Cognitive Literary Research as a Showcase of Multidisciplinary Concept of Science". Zagadnienia Rodzajo'w Literackich, LVII, Z.1, PL ISSN 0084- 4446, 2014, pp. 301-304.

Mc Hale, Brian. Postmodernist Fiction. Routledge, 1987.

Rosenblatt, Louise. "The Literary Transaction: Evocation and Response". in Children's Literature, Theory Into Practice, Taylor\& Francis Ltd, Vol. 21, No. 4, Autumn, 1982, pp. 268- 277, http://www.jstor.org/stable/1476352.

-"The Aesthetic Transaction". The Journal of Aesthetic Education. University of Illinois, Vol. 20, No. 4, $20^{\text {th }}$ Anniversary Issue, Winter, 1986, pp. 122- 128, http://www.jstor.org/stable/3332615

-"Theory and Practice: An Interview With Louise M. Rosenblatt". Interv. Nicholas J. Karolides, in Collaborations, Language Arts, Vol. 77, No. 2, November, 1999, pp. 158-170, http://www.jstor.org/stable/41484075. 
Sentov, Ana. "The Postmodern Perspective of Time in Peter Ackroyd's Hawksmoor". Linguistics and Literature, Vol. 7, No.1, 2009, pp. 123-

134.

Tally, Robert T. "To Draw a Map is to Tell a Story: Interview With Dr. Robert T. Tally JR on Geocriticism". Interv. Katiuscia Darici, Revista Forma, Vol II, Primavera, 2015, pp. 27- 36, revistaforma//voliiprimavera2015//ISSN 2013- 7761//28.

Turner, Mark and Gilles Fauconnier. "A Mechanism of Creativity". in Poetics Today, Metaphor and Beyond: New Cognitive Development, Duke University Press, Vol. 20, No. 3, Autumn, 1999, pp. 397- 418, http://www.jstor.org/stable/1773272. 